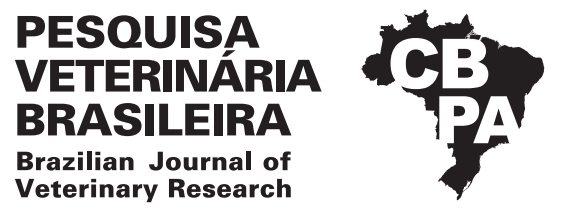

Pesq. Vet. Bras. 39(7):510-515, July 2019 DOI: 10.1590/1678-6160-PVB-5916

Original Article

Small Animal Diseases

ISSN 0100-736X (Print)

ISSN 1678-5150 (Online)

\title{
Dirofilaria immitis infection in dogs in Algodoal Island, Brazilian Amazon ${ }^{1}$
}

\author{
Hanniele R. Moreira², Ene A.O. Madeira², Dalvarina N. Lima Cunha², \\ Alessandra Scofield ${ }^{2}$, Gustavo Góes-Cavalcante², Isis Abel ${ }^{2}$ (D), \\ Ricardo J.P.S. Guimarães ${ }^{3}$ (D) and Julio I. Fernandes ${ }^{4 *}$ (D)
}

\begin{abstract}
Moreira H.R., Madeira E.A.O, Lima Cunha D.N., Scofield A., Góes-Cavalcante G., Abel I., Guimarães R.J.P.S. \& Fernandes J.I. 2019. Dirofilaria immitis infection in dogs in Algodoal Island, Brazilian Amazon. Pesquisa Veterinária Brasileira 39(7):510-515. Instituto de Medicina Veterinária, Universidade Federal do Pará, Rodovia BR-316 Km 61, Bairro Saudade, Castanhal, PA 68740-970, Brazil. E-mail: vetjulio@yahoo.com.br

Dirofilaria immitis, a parasite that mainly infects domestic or wild canids, but can infect felines or humans as well, is frequent in many Brazilian areas. The main objective of this research was to determine the prevalence of natural canine infection at the Algodoal-Maiandeua Island complex, in the coastal region of the state of Pará, Brazil. A total of 67 dogs were sampled for blood microfilariae detection and for D. immitis DNA detection. Microfilaria and D. immitis DNA could be detected in $35.8 \%$ (24/67) of the animals. In one dog's sample no microfilariae were detected, but the PCR was positive, suggesting that either larvae recently were eliminated or adults died shortly before sample collecting. Therefore, it can be concluded that the occurrence of D. immitis is a health threat for domestic and wild canids at the Island of Algodoal, as well as for feline or human health.
\end{abstract}

INDEX TERMS: Occurrence, canids, Dirofilaria immitis, infection, dogs, Algodoal Island, Brazilian Amazon, heartworm, PCR.

RESUMO.- [Infecção por Dirofilaria immitis em cães na Ilha de Algodoal, Amazônia brasileira.] Dirofilaria immitis, um parasito que infecta principalmente canídeos domésticos ou selvagens, embora também possa infectar felinos e humanos, é frequente em muitas áreas do Brasil. 0 objetivo deste estudo foi determinar a ocorrência da infecção natural em cães provenientes do complexo da Ilha de Algodoal-Maiandeua, região litorânea do estado do Pará, Brasil. Um total de 67 cães tiveram o sangue coletado para detecção de microfilárias de D. immitis e seu DNA. Microfilárias e o DNA de D. immitis foram detectados em 35,8\% (24/67) dos animais. Na amostra de um animal, não foram observadas microfilárias, mas o seu DNA foi detectado, sugerindo que as larvas tenham sido recentemente eliminadas ou os adultos tenham morrido

\footnotetext{
${ }^{1}$ Received on December 23, 2018.

Accepted for publication on February 12, 2019.

${ }^{2}$ Instituto de Medicina Veterinária, Universidade Federal do Pará (UFPA), Rodovia BR-316 Km 61, Bairro Saudade, Castanhal, PA 68740-970, Brazil.

${ }^{3}$ Instituto Evandro Chagas, Laboratório de Geoprocessamento, Ananindeua, PA 67030-000, Brazil.

${ }^{4}$ Departamento de Medicina e Cirurgia Veterinária, Universidade Federal Rural do Rio de Janeiro (UFRRJ), Seropédica, RJ 23890-000, Brazil. *Corresponding author: vetjulio@yahoo.com.br
}

antes da coleta da amostra. Portanto, pode-se concluir que a ocorrência de $D$. immitis é uma ameaça à saúde de canídeos domésticos no complexo da Ilha de Algodoal-Maiandeua, bem como para felinos e seres humanos.

TERMOS DE INDEXAÇÃO: Ocorrência, cães, infecção, Dirofilaria immitis, verme do coração, PCR, Ilha de Algodoal, Amazônia brasileira.

\section{INTRODUCTION}

Dirofilariasis is a parasitic disease caused by filarial worm Dirofilaria immitis (Leidy 1856), also known as the heartworm (Bolio-Gonzalez et al. 2007), affecting mainly domestic and wild canids (Batista et al. 2008). Humans and felines, which may be accidental hosts, are more susceptible to infection in areas with high prevalence of the canine disease (Garcez et al. 2006, Mirahmadi et al. 2017), which is distributed all over the globe (Bolio-Gonzalez et al. 2007, Bowman \& Atkins 2009, Hou et al. 2011, Simsek et al. 2011, Montoya-Alonso et al. 2015, Bendas et al. 2017). It has been found in every geographical region of Brazil, with prevalence rates over the last decade ranging from 2.1\% in Florianópolis, in the Southern state of Santa Catarina (SC), to $62.2 \%$ in Armação de Búzios, in the Southeastern state of Rio de Janeiro (RJ) (Silva et al. 2008, 
Furtado et al. 2009, Ogawa et al. 2013, Labarthe et al. 2014, Soares et al. 2014, Ramos et al. 2015).

Methods and techniques with different analytical sensitivities are employed to diagnose infection by $D$. immitis. The most common diagnosis techniques are the identification of microfilariae on light microscopy, PCR and variations of this method for DNA detection, anti-D. immitis antibody detection by means of the enzyme-linked immunosorbent assay (ELISA) and the detection of antigens by immunochromatography (Traversa et al. 2010, Simsek et al. 2011, Rojas et al. 2015, Shalini et al. 2018).

Infection in a given region can be influenced by different factors, such as the diversity and quantity of mosquitoes in the area, climate changes, anthropic action and the presence of animals not receiving chemoprophylaxis (Bowman \& Atkins 2009, Genchi et al. 2011, Labarthe et al. 2014). In the North region of Brazil, epidemiological studies on canine dirofilariasis are still incipient. In the state of Pará, D. immitis infection has been reported in dogs living in coastal areas, such as the islands of Algodoal (Castro et al. 2012, Furtado et al. 2012) and Marajó (Soares et al. 2014, Argôlo et al. 2018).

The Algodoal-Maiandeua island, part of the municipality of Maracanã, in the northeastern mesoregion of the state of Pará and part of the Northeastern Coastal Plain of Pará (João et al. 2013), has approximately $23.78 \mathrm{~km}^{2}$ in area and its environment is influenced by the geographical proximity to the Amazon River. For its regional biota and fragile ecosystem - composed of sandbanks, dunes, mangroves and lakes - the island entered the status of Environmentally Protected Area (APA - State Law of Pará No. 5621, Pará 1990). The climate is warm and humid, and its population is distributed among a complex of four villages (Algodoal, Camboinha, Mocooca and Fortalezinha). The island's economy relies strongly on tourism, with an intense flow of people and domestic animals. This calls for health regulation measures, especially with regard to infections transmitted by arthropods, including D. immitis. The island houses a great number of free-ranging or stray dogs who do not get proper veterinary care, which favors a high incidence of these infections (Castro et al. 2012, Furtado et al. 2012).

This work aimed to identify the frequency of natural infection with $D$. immitis in dogs in the villages composing the island of Algodoal-Maiandeua.

\section{MATERIALS AND METHODS}

Study area. Algodoal or Maiandeua island ( $0^{\circ} 34^{\prime} 45^{\prime \prime}$ to $0^{\circ} 37^{\prime} 30^{\prime \prime}$ S and $47^{\circ} 32^{\prime} 05^{\prime \prime}$ to $47^{\circ} 34^{\prime} 12^{\prime \prime} \mathrm{W}$ ), with $3,100.34$ ha, is located in the municipality of Maracanã, microregion Salgado and mesoregion Northeast of the state of Pará. The island is composed of four villages: Vila de Algodoal, Vila de Camboinha, Vila de Fortalezinha and Vila de Mocooca. The city of Maracanã is located at $165 \mathrm{~km}$ by road from the state capital. Algodoal is accessed by river from Marudá port (city of Marapanim), a crossing which lasts approximately 40 minutes to Algodoal village (Ideflor-bio 2018).

Sample size and sampling. The communities composing the Algodoal island complex were visited from July to September 2013. The sample size was calculated with the aid of the Statcalc tool of software EpiInfo 3.5.3 considering an estimated human population of 2,050 inhabitants (Algodoal 2013), an estimated canine population of 293 dogs, 176 households with at least one dog, expected frequency of $40 \%, \beta$ error of $20 \%$ and $\alpha$ error of 0.01 , which amounts to a total of 50 households for sampling. At the first stage, the proportionate stratified sampling, which considered each community as a stratum, led to the visit of 29 households in Vila de Algodoal, five in Camboinha, ten in Fortalezinha and six in Mocooca. The second stage involved systematic sampling, where households with at least one dog were included in the sample. However, in cases where these households had more than one dog, all animals were submitted to the tests.

Georeferencing and spatial distribution map. All households included in the study have been georeferenced by a GPS MAP (60CSX, Garmin, EUA) for subsequent spatial distribution of $D$. immitis infected and non-infected animals. The maps were drawn on software ArcGis 10.3 using the Copernicus Sentinel-2 images (http://open.esa.int/) from 9 August, 2017 and the 2012 soil use and cover map by the State Secretary for the Environment (SEMA). The coordinates of residences without infected animals, as per the techniques employed in this study, were represented as green dots on the map, whereas those with at least one infected animal were represented as red dots.

Sample collection. A total of $5 \mathrm{~mL}$ of blood was collected from the cephalic vein of each animal and stored in tubes containing ethylenediamine tetra acetic acid (EDTA), with a final concentration of approximately $1.8 \mathrm{mg} / \mathrm{mL}$ of blood.

Techniques for microfilaremia detection. All samples were submitted to three techniques for detection of microfilariae: fresh and thick blood smears and the Knott technique modified by Newton \& Wright (1956), which was also used to identify the microfilariae found. In sum, the fresh blood smear technique consists in using a drop of blood with anticoagulant on a microscopy slide covered by a glass cover slip of $10 \times 10 \mathrm{~mm}$. The thick blood smear technique uses two drops of blood on a microscope slide, spread with the aid of microhematocrit tubes in circular movements and air dried by manual movement. The slides were examined on an optical microscope with magnification of 400× (De Carli \& Tasca 2007).

The Knott technique modified by Newton \& Wright (1956) is performed by diluting $1 \mathrm{~mL}$ of blood into $9 \mathrm{~mL}$ of formalin $2 \%$ with subsequent centrifuging (1.500rpm for $5 \mathrm{~min}$ ). Then, the supernatant was discarded and the precipitate examined between slide and cover slip by light microscopy (magnification of 100 or $400 \times$ ) for detection and morphological identification of microfilariae. Distinction of the microfilariae was based on the evaluation of their morphological characteristics, especially in the anterior and posterior ends, according to Genchi et al. (2007). The samples containing immature forms of D. immitis were registered as such.

Polymerase chain reaction (PCR). A commercial kit (AxyPrep ${ }^{\mathrm{TM}}$ Multisource Genomic DNA Miniprep Kit -Axygen-Biosciences, EUA) was used to extract the genomic DNA of the dogs' blood samples. The procedure was done according to the manufacturer's instructions. All samples were submitted to a PCR using primers $12 \mathrm{SF}$ (5'-GTTCCAGAATAATCGGCTA-3') and 12SRdeg (5'-ATTGACGGATG(AG) TTTGTACC-3'), which amplify a product of 500 base pairs (bp) in the region of gene $12 \mathrm{~S}$ rDNA, highly conserved for nematode species (Casiraghi et al. 2004). The samples tested positive in the first PCR were submitted to a second PCR using primers 12SF2B (5'-TTTTTACTTTTTTGGTAATG-3') and 12SRdeg (5'-ATTGACGGATG(AG) TTTGTACC-3'), which amplify a product of $204 \mathrm{bp}$ in the region of gene 12S rDNA of $D$. immitis (Gioia et al. 2010). The protocols were used according to Gioia et al. (2010) with modifications.

The amplification solution used for the reactions was made up of $2.5 \mathrm{mM}$ of Buffer $(100 \mathrm{mM}$ of Tris- $\mathrm{HCl}, \mathrm{pH} 8.5$ and $500 \mathrm{mM}$ of $\mathrm{KCl}$ ), $1.5 \mathrm{mM}$ of $\mathrm{MgCl}_{2}, 0.5 \mathrm{mM}$ of each dNTP (dATP, dGTP, dCTP and dTTP), 1 pmol of each primer, 0.5 unit of Taq DNA polymerase 
(Ludwig Biotec $^{\circledR}$ ) and $5 \mu \mathrm{L}$ of DNA $(\sim 43.4 \eta \mathrm{g} / \mu \mathrm{L})$, amounting a final volume of $25 \mu \mathrm{L}$.

The reactions were performed in a thermocycler (Veriti 96 Well Thermal Cycler - Applied Biosystems ${ }^{\circledR}$, USA) using a temperature protocol with an initial stage of denaturation at $92^{\circ} \mathrm{C}$ for $1 \mathrm{~min}$, followed by 40 cycles of $92^{\circ} \mathrm{C}$ for $30 \mathrm{~s}, 49^{\circ} \mathrm{C}$ for $45 \mathrm{~s}$ and $72^{\circ} \mathrm{C}$ for $1 \mathrm{~min}$, with a final extension of $72^{\circ} \mathrm{C}$ for $10 \mathrm{~min}$.

All reaction products were analyzed by $2 \%$ agarose gel electrophoresis and staining with ethidium bromide $(5 \mathrm{mg} / \mathrm{mL})$. The size of amplified products was estimated using a pattern of 100 base pairs (Ladder 50 pb-Ludwig Biotec ${ }^{\circledR}$ ) and a transilluminator coupled to a photodocumentation system was used for visualization (Quantum-ST4 1000/26M).

Statistical analysis. The dogs were considered infected when the microfilariae species was identified using the modified Knott technique or when the D. immitis-specific PCR was positive. In order to evaluate the association of the variables used in this study with infection by D. immitis, the data obtained was submitted to an exploratory analysis and subsequently to chi-squared and Fisher's exact test (Sampaio 2002), using the Statcalc tool of software EpiInfo 3.5.2 with a level of significance of $95 \%(\mathrm{p} \leq 0.05)$.

\section{RESULTS}

Sixty-seven (67) animals from six months of age were included in the study and stratified per village as follows: 40 dogs from Vila de Algodoal, five from Camboinha, ten from Mocooca, and 12 from Fortalezinha (Fig.1), where 38 were male and 29 female. Almost all animals were mongrel (66/67) and one animal was a Pit Bull Terrier. The study included animals aged from six to 12 months old (21/67), one and three years old (32/67) and above three years old (14/67).

Of the 67 blood samples collected, 35.8\% (24/67) were considered to have been taken from animals infected with Dirofilaria immitis (Table 1). Vila de Camboinha was the only study location where infected animals were not identified. Vila do Algodoal presented the highest rate of infected animals, $47.5 \%$ (19/40), compared to the infection rate among dogs from Fortalezinha or Mocooca, 25\% (3/12) and 20\% (2/10) respectively, although there was no statistical difference $\left(x^{2}=3.73, p=0.1549, G L=2\right)$.

Male dogs were more infected $(47.4 \%, 18 / 38)$ than females $(20.7 \%, 6 / 29)\left(x^{2}=4, p=0.0455, G L=1\right)$. Younger dogs, regardless of their gender, were less infected $\left(x^{2}=6.34\right.$,
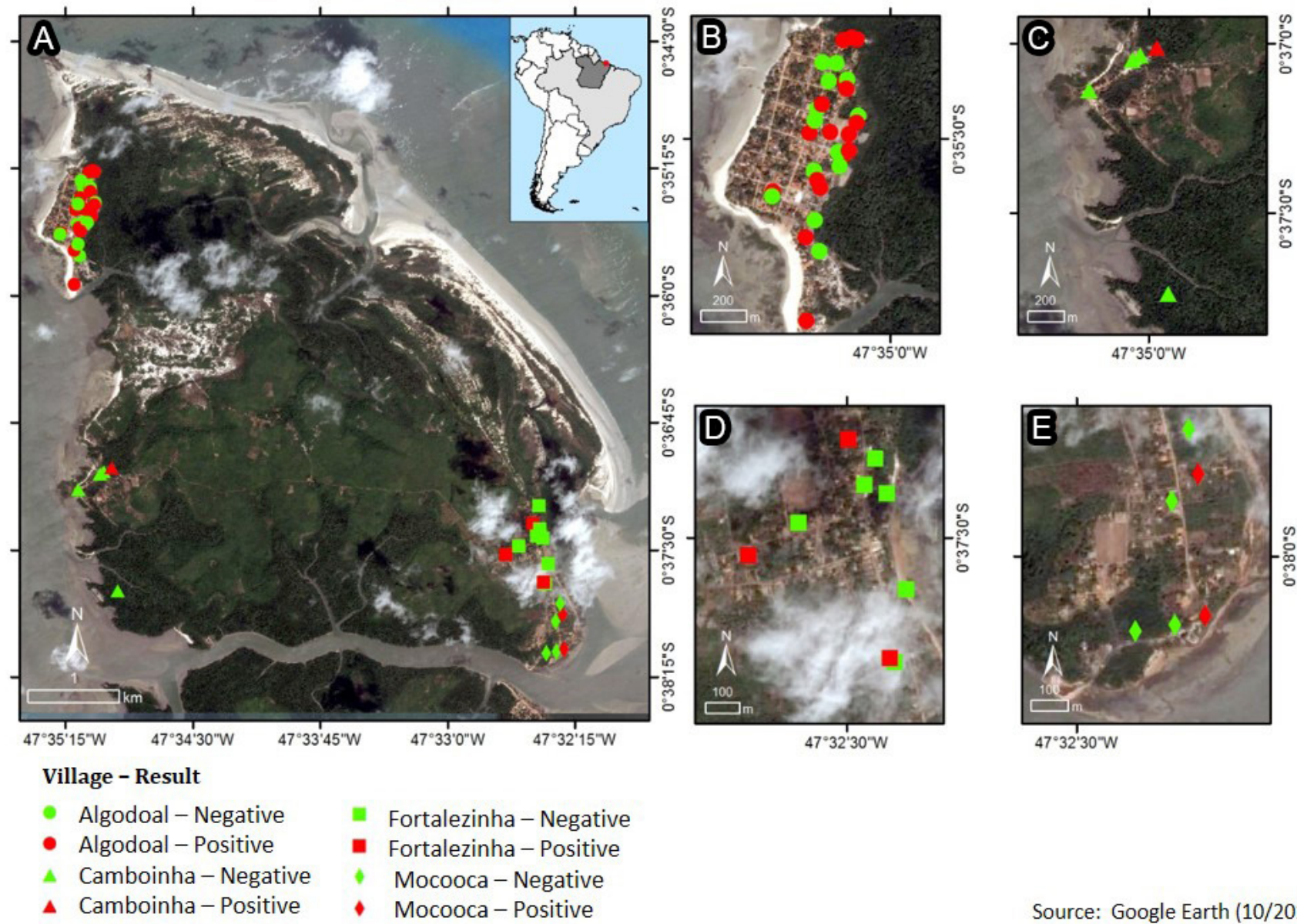

Source: Google Earth (10/2015) Map projection WGS84

Fig.1. (A) Map of Algodoal island using the images of Copernicus Sentinel-2 from August 9, 2017 and data on soil use and cover provided by SEMA. Each marker represents one household included in the study, according to the area studied. Red markers represent households with at least one infected animal; green markers represent households without infected animals in the villages of (B) Algodoal, (C) Camboinha, (D) Fortalezinha and (E) Mocooca. 
Table 1. Comparative results between microfilaria detection methods: modified Knott (K), thick bead (TB), fresh blood (FB), and detection of nucleic material (PCR) of Dirofilaria immitis microfilariae in dogs on Algodoal Island, Pará state, from July to September 2013

\begin{tabular}{ccccc}
\hline & & \multicolumn{3}{c}{ Method } \\
\cline { 2 - 5 } & K, TB, FB and PCR & K, TB, and PCR & K and PCR & 1 \\
Total* \\
\hline Positive & 19 & 4 & 0 & 24 \\
Negative & 42 & 0 & 1 & 42 \\
Total* & 61 & 4 & 66
\end{tabular}

* One sample did not present microfilariae, but PCR was positive.

Table 2. Number of dogs ranked by gender and age regarding the occurrence of Dirofilaria immitis microfilariae on Algodoal Island, Pará state, from July to September 2013

\begin{tabular}{|c|c|c|c|c|c|c|c|}
\hline \multirow[b]{2}{*}{ Number of dogs } & \multicolumn{3}{|c|}{ Female } & \multicolumn{3}{|c|}{ Male } & \multirow[b]{2}{*}{ Total } \\
\hline & $<1$ year & $\begin{array}{c}>1 \text { year and } \\
<3 \text { years }\end{array}$ & >3 years & $<1$ year & $\begin{array}{c}>1 \text { year and } \\
<3 \text { years }\end{array}$ & $>3$ years & \\
\hline Infected* & 0 & 2 & 4 & 3 & 12 & 3 & 24 \\
\hline Free & 8 & 10 & 5 & 10 & 8 & 2 & 43 \\
\hline Total** & 8 & 12 & 9 & 13 & 20 & 5 & 67 \\
\hline$\%$ Infected & & $16.7^{\mathrm{a}}$ & 44.4 & 23.1 & $60^{\mathrm{b}}$ & 60 & 35.8 \\
\hline
\end{tabular}

* Modified Knott technique, ${ }^{* *}$ superscript different letters indicate $\mathrm{x}^{2}=4.1$ and $p=0.04295$.

$\mathrm{p}=0.0420, \mathrm{GL}=2$ ). Although no female dog below one year old was infected among the study population, females were less infected than males only in the age range from one to three years old $\left(x^{2}=4.1, p=0.0429, G L=1\right)$ (Table 2).

Of the 24 blood samples presenting microfilariae with D. immitis morphology, young forms with characteristics of Acanthocheilonema reconditum were also detected in 16 animals (66.7\%). All animals with microfilariae also presented amplified DNA with primer pair 12SF and 12SRdeg and primers 12SF2B and 12SRdeg (24/24). On the other hand, in a sample without microfilariae, D. immitis DNA was detected by means of the same methodology. The fresh blood smear technique failed to detect microfilariae in five samples, whereas the thick blood technique failed to detect it in one sample (Table 1).

\section{DISCUSSION}

Canine infection with Dirofilaria immitis has been studied across the five regions of Brazil with different infection rates recorded in 14 out of 26 states (Bendas et al. 2017). Therefore, it is known that rates can vary over time and according to environmental or socioeconomic conditions (Labarthe et al. 2014). The most widely studied area in the state of Pará is the island of Algodoal, a touristic destination of the region where domestic animal health services are incipient. Vila do Algodoal is the village presenting the largest human resident population, in addition to being the gateway to the island; therefore, it concentrates the largest canine population. Most of the animals infected with $D$. immitis were found in this village $(79,2 \%)$, which is likely to be due to the sample size. The prevalence rates show that infected dogs were found in all of the different villages of the island, except for the smallest one, Camboinha. The sample size was influenced by the size of each village, so that no difference was observed among prevalence rates. Nevertheless, it was observed that $35.8 \%$ of the dogs in Algodoal island have microfilaremia of the $D$. immitis species, which indicates that all dogs residing or visiting the island should receive specific chemoprophylaxis. Additionally, previous reports have shown the need to use prophylaxis upon reporting that 46.8\% (Furtado et al. 2012) and 42.4\% (Castro et al. 2012) of the dogs in Algodoal village had microfilaremia in January and March 2012 respectively. As this study was carried out more than one year after the first records, in which prevalence rates for Algodoal village were similar to the findings of this study (47.5\%), it may be inferred that animal welfare in the island has not improved in spite of the work done.

The findings of this study and the ones published in the islands of Algodoal (Castro et al. 2012, Furtado et al. 2012) and Marajó (Furtado et al. 2009) suggest that these islands in Pará have favorable environmental conditions for the transmission of $D$. immitis infection. It may be suggested that the most prominent of these conditions are, as in other regions of Brazil (Paiva 2009): high temperatures and relative humidity maintained throughout the year, an extensive area of preserved nature and the rare characteristic of sediment deposition along the coast in areas juxtaposed to the Amazon River, forming small sand strips.

In Brazil and elsewhere, filarial co-infection in dogs with microfilaremia has been diagnosed, where the species detected most often are Acanthocheilonema reconditum and D. immitis (Brito et al. 2001, Mar et al. 2002, Reifur et al. 2004, Argôlo et al. 2018). Co-infection with A. reconditum and $D$. immitis was diagnosed based on the morphological identification of microfilariae; however, due to the diversity and morphological similarity between immature forms of filarial species found in the Amazon, the morphological diagnosis must be interpreted with care, as it was not associated with molecular diagnosis and phylogenetic analysis (Argôlo et al. 2018). The fact that microfilariae were not detected by the 
fresh and thick blood smear technique in five animals may reflect a low concentration of microfilariae, as the analytical sensitivity threshold of these tests is of $30 \mathrm{Mf} / \mathrm{mL}$ (Bowman \& Mannella 2011).

It is worth highlighting that microfilariae were not found in the blood sample of a five-year-old female dog from Algodoal village, although the PCR detected the parasite's DNA. Given that finding D. immitis DNA in blood samples depends on the presence of microfilariae in the sample (Rossi et al.2010), it is possible that: $i$ ) the dog did not have the disease and adult microfilariae had died, releasing DNA; ii) the microfilariae died as a result of sample manipulation; iii) the microfilariae died, freeing the dog from the disease months before the blood sample collection, as has been observed in animals treated with doxycycline (Rossi et al. 2010).

The infection was found more often among male dogs from one to three years old than among females within the same age range, which is not in line with other Brazilian studies that report not finding any differences between genders among infected animals (Almeida et al. 2001, Silva et al. 2008, Labarthe et al. 2014). It is likely that females are cared for differently in Algodoal Island, which makes them less exposed to mosquitoes than males, or that they receive some protective treatment.

The chances of transmission via blood from infecting mosquitoes to susceptible hosts increase over time so much that young animals usually present lower infection rates (Hou et al. 2011, Labarthe et al. 2014), although in hyperenzootic areas, time of residence in the region has not influenced the prevalence rate (Labarthe et al. 2014). In addition, it must be considered that the prepatent period of the infection is of at least six months, which may disguise the results of animals under one year old (American Heartworm Society 2018).

The expressive prevalence rates of canine infection observed in the state of Pará, which vary from $32.4 \%$ to $46.8 \%$ (Castro et al. 2012, Furtado et al. 2009, Furtado et al. 2012), associated with the results of this study (35.8\%), show that transmission of $D$. immitis is frequent, especially in the coastal and touristic areas of the state. Therefore, considering the importance of unified health care, especially since the parasite infects domestic or wild canids and human beings, all public health agents in the region must be committed to educating the population residing and visiting the region as to the risks of infection and prevention measures.

\section{CONCLUSION}

It may be concluded that the expressive prevalence rates of Dirofilaria immitis in the villages composing Algodoal Island, associated to the animals' mobility, the island's environmental characteristics and the flow of inhabitants and visitors, points to the need to implement control and prophylaxis measures, which are responsibility of healthcare professionals acting in the corresponding fields of study.

Acknowledgements.- The authors thank CNPq (Conselho Nacional de Desenvolvimento Científico e Tecnológico) and Capes (Coordenação de Aperfeiçoamento de Pessoal de Nível Superior, Brazil) for the financial support (scholarship) provided during this study.

Conflict of interest statement.- The authors declare no conflict of interest.

\section{REFERENCES}

Algodoal 2013. Isto é Amazônia. Available at <http://www.istoeamazonia. com.br> Accessed on Jul. 8, 2013.

Almeida M.A.O., Barros M.T.G., Santos E.P., Ayres M.C.C., Guimarães J.E. \& Gondim L.F.P. 2001. Parasitismo de cães por microfilárias de Dirofilaria immitis: influência da raça, sexo e idade. Revta Bras. Saúde. Prod. Anim. 2(3):59-64.

American Heartworm Society 2018. Current Canine Guidelines for the Prevention, Diagnosis, and Management of Heartworm Infection in Dogs. Wilmington. Available at: <https://heartwormsociety.org/images/pdf/2018AHS-Canine-Guidelines.pdf> Accessed on Feb. 17, 2019.

Argôlo E.G.G., Reis T., Fontes D.A.T., Gonçalves E.C., Giese E.G., Melo F.T.V., Santos J.N. \& Furtado A.P. 2018. Canine filariasis in the Amazon: Species diversity and epidemiology of these emergent and neglected zoonoses. PLoS One 13(7):1-9. <http://dx.doi.org/10.1371/journal.pone.0200419> $<$ PMid:29995959>

Batista N.C., Bezerra N.M., Gadelha I.C.N., Borges M.E.O., Cabral S.O., Dias C.E.V., Sakamoto S.M. \& Freitas C.I.A. 2008. Utilização de kit comercial anigen rapid Dirofilaria immitis Ag em comparação com a técnica de Knott modificada no diagnóstico da incidência de cães portadores da dirofilariose. Acta Vet. Brasilica 2(3):76-79.

Bendas A.J.R., Mendes-de-Almeida F., Guerrero J. \& Labarthe N. 2017. Update on Dirofilaria immitis epidemiology in South America and Mexico: literature review. Braz. J. Vet. Res. Anim. Sci. 54(4):319-329. <http://dx.doi. org/10.11606/issn.1678-4456.bjvras.2017.132572>

Bolio-Gonzalez M.E., Rodriguez-Vivas R.I., Sauri-Arceo C.H., Gutierrez-Blanco E., Ortega-Pacheco A. \& Colin-Flores R.F. 2007. Prevalence of the Dirofilaria immitis infection in dogs from Merida, Yucatan, Mexico. Vet. Parasitol. 148(2):166-169. <http://dx.doi.org/10.1016/j.vetpar.2007.05.019> <PMid:17630215>

Bowman D.D. \& Atkins C.E. 2009. Heartworm biology, treatment and control. Vet. Clin. N. Am., Small Anim. Pract. 39(6):1127-1158, vii. <http://dx.doi. org/10.1016/j.cvsm.2009.06.003><PMid:19932367>

Bowman D.D. \& Mannella C. 2011. Macrocyclic lactones and Dirofilaria immitis microfilariae. Top Companion Anim. Med. 26(4):160-172. <http://dx.doi. org/10.1053/j.tcam.2011.07.001><PMid:22152603>

Brito A.C., Vila-Nova M.C., Rocha D.A.M., Costa L.G., Almeida W.A.P., Viana L.S., Lopes Junior R.R., Fontes G., Rocha E.M.M. \& Regis L. 2001. Prevalência da filariose canina causada por Dirofilaria immitis e Dipetalonema reconditum em Maceió, Alagoas, Brasil. Cad. Saúde Públ. 17(6):1497-1504. <http:// dx.doi.org/10.1590/S0102-311X2001000600021><PMid:11784911>

Casiraghi M., Bain O., Guerrero R., Martin C., Pocacqua V., Gardner S.L., Franceschi A. \& Bandi C. 2004. Mapping the presence of Wolbachia pipientis on the phylogeny of filarial nematodes: evidence for symbiont loss during evolution. Int. J. Parasitol. 34(2):191-203. <http://dx.doi.org/10.1016/j. ijpara.2003.10.004><PMid:15037105>

Castro L.R.S., Ramos E.L.M., Almeida V.T., Cunha D.N.L., Trindade C.E.D., Miranda A.L.D. \& Fernandes J.I. 2012. Ocorrência de Dirofilaria immitis em cães em município do estado do Pará diagnosticados por microfilaremia. Anais XVII Congresso Brasileiro de Parasitologia Veterinária, São Luis, MA, p.125. (Resumo)

De Carli G.A. \& Tasca T. 2007. Métodos e técnicas para a identificação de parasitos do sangue, p.299-329. In: De Carli G.A. (Ed), Parasitologia Clínica: seleção de métodos e técnicas de laboratório para o diagnóstico das parasitoses humanas. $2^{\underline{a}}$ ed. Atheneu, São Paulo.

Furtado A.P., Argôlo E.G.G., Bernal M.K.M., Costa H.J.A., Barbosa J.F., Pezutti J.C.B., Giese E.G. \& Santos J.N. 2012. Microfilaremia em cães na comunidade de Algodoal, Ilha de Maiandeua, município de Maracanã, Pará, Brasil. Anais XVII Congresso Brasileiro de Parasitologia Veterinária, São Luis, MA, p.126. (Resumo) 
Furtado A.P., Carmo E.S., Giese E.G., Vallinoto A.C.R., Lanfredi R.M. \& Santos J.N. 2009. Detection of filariasis in Marajó Island, Brazil by classic and molecular methods. Parasitol. Res. 105(6):1509-1515. <http://dx.doi. org/10.1007/s00436-009-1584-9><PMid:19693539>

Garcez L.M., Souza N.F., Mota E.F., Dickson L.A.J., Abreu W.U., Cavalcanti V.F.N. \& Gomes P.A.F. 2006. Focos de dirofilariose canina na Ilha do Marajó: um fator de risco para a saúde humana. Revta Soc. Bras. Med. Trop. 39(4):333336. <http://dx.doi.org/10.1590/S0037-86822006000400003>

Genchi C., Mortarino M., Rinaldi L., Cringoli G., Traldi G. \& Genchi M. 2011. Changing climate and changing vector-borne disease distribution: the example of Dirofilaria in Europe. Vet. Parasitol. 176(4):295-299. <http:// dx.doi.org/10.1016/j.vetpar.2011.01.012><PMid:21300439>

Genchi C., Venco L. \& Genchi M. 2007. Guideline for the laboratory diagnosis of canine and feline Dirofilaria infections, p.139-144. In: Ibid. (Eds), Dirofilaria immitis and D. repens in dog and cat and human infections. Available at <https:// pdfs.semanticscholar.org/9b6a/19110f46ca486c52d77963d9502271dbaf81. pdf> Accessed on Aug. 13, 2018.

Gioia G., Lecová L., Genchi M., Ferri E., Genchi C. \& Mortarino M. 2010. Highly sensitive multiplex PCR for simultaneous detection and discrimination of Dirofilaria immitis and Dirofilaria repens in canine peripheral blood. Vet. Parasitol. 172(1/2):160-163. <http://dx.doi.org/10.1016/j. vetpar.2010.04.027><PMid:20483540>

Hou H., Shen G., Wu W., Gong P., Liu Q., You J., Cai Y., Li J. \& Zhang X. 2011. Prevalence of Dirofilaria immitis infection in dogs from Dandong, China. Vet. Parasitol. 183(1/2):189-193. <http://dx.doi.org/10.1016/j. vetpar.2011.06.016><PMid:21889850>

Ideflor-Bio 2018. Área de Proteção Ambiental de Algodoal-Maiandeua. Available at <http://ideflorbio.pa.gov.br/unidades-de-conservacao/ regiao-administrativa-nordeste/area-de-protecao-ambiental-de-algodoalmaiandeua/> Accessed on Aug. 29, 2018.

João X.S.J., Teixeira S.G. \& Fonseca D.D.F. 2013. Geodiversidade do estado do Pará. Companhia de Pesquisa de Recursos Minerais (CPRM), Belém. 256p.

Labarthe N.V., Paiva J.P., Reifur L., Mendes-de-Almeida F., Merlo A., Carvalho Pinto C.J., Juliani P.S., Almeida M.A. \& Alves L.C. 2014. Updated canine infection rates for Dirofilaria immitis in areas of Brazil previously identified as having a high incidence of heartworm-infected dogs. Parasit. Vectors 7(1):493. <http://dx.doi.org/10.1186/s13071-014-0493-7> <PMid:25376238>

Mar P.H., Yang I.C., Chang G.N. \& Fei A.C.Y. 2002. Specific polymerase chain reaction for differential diagnosis of Dirofilaria immitis and Dipetalonema reconditum using primers derived from internal transcribed spacer region 2 (ITS2). Vet. Parasitol. 106(3):243-252. <http://dx.doi.org/10.1016/ S0304-4017(02)00032-8><PMid:12062512>

Mirahmadi H., Maleki A., Hasanzadeh R., Ahoo M.B., Mobedi I. \& Rostami A. 2017. Ocular dirofilariasis by Dirofilaria immitis in a child in Iran: a case report and review of the literature. Parasitol. Int. 66(1):978-981.<http:// dx.doi.org/10.1016/j.parint.2016.10.022><PMid:27815230>

Montoya-Alonso J.A., Carretón E., Simón L., González-Miguel J., García-Guasch L., Morchón R. \& Simón F. 2015. Prevalence of Dirofilaria immitis in dogs from Barcelona: validation of a geospatial prediction model. Vet. Parasitol. 212(3/4):456-459. <http://dx.doi.org/10.1016/j.vetpar.2015.06.025> $<$ PMid:26162560>
Newton N.L. \& Wright W.H. 1956. The occurrence of a dog filarid other than Dirofilaria immitis in the United States. J. Parasitol. 42(3):246-258. <http:// dx.doi.org/10.2307/3274849><PMid:13332492>

Ogawa G.M., Cruz E.N., Cunha P.N. \& Camargo L.M. 2013. Canine heartworm disease in Porto Velho: first record, distribution map and occurrence of positive mosquitoes. Revta Bras. Parasitol. Vet. 22(4):559-564. <http:// dx.doi.org/10.1590/S1984-29612013000400017> <PMid:24473882>

Paiva J.P. 2009. Interação entre filarídeos, vetores e Wolbachia sp. Hertig, 1936 um foco ativo de transmissão de Dirofilaria immitis (Leidy, 1856) como modelo. Doctoral Dissertation, Universidade Federal Fluminense, Niterói, Rio de Janeiro.

Pará 1990. Lei Estadual no 5.621. Available at <https://www.semas.pa.gov. br/1990/11/27/9778/> Accessed on Jul. 5, 2018.

Ramos D.G.S., Zocco B.K.A., Torres M.M., Braga I.A., Pacheco R.C. \& Sinkoc A.L. 2015. Helminths parasites of stray dogs (Canis lupus familiaris) from Cuiabá, Midwestern of Brazil. Semina, Ciênc. Agrárias 36(2):889-894.

Reifur L., Thomaz-Soccol V. \& Montiani-Ferreira F. 2004. Epidemiological aspects of filariosis in dogs on the coast of Paraná state, Brazil: with emphasis on Dirofilaria immitis. Vet. Parasitol. 122(4):273-286. <http:// dx.doi.org/10.1016/j.vetpar.2004.05.017><PMid:15262005>

Rojas A., Rojas D., Montenegro V.M. \& Baneth G. 2015. Detection of Dirofilaria immitis and other arthropod-borne filarioids by an HRM real-time qPCR, blood-concentrating techniques and aserological assay in dogs from Costa Rica. Parasit. Vectors 8(1):170. <http://dx.doi.org/10.1186/s13071-0150783-8><PMid:25851920>

Rossi M.I.D., Paiva J.P., Bendas A., Mendes-de-Almeida F., Knackfuss F., Miranda M., Guerrero J., Fernandes O. \& Labarthe N. 2010. Effects of doxycycline on the endosymbiont Wolbachia in Dirofilaria immitis (Leidy, 1856), naturally infected dogs. Vet. Parasitol. 174(1/2):119-123.<http://dx.doi. org/10.1016/j.vetpar.2010.07.019><PMid:20810215>

Sampaio I.B.M. 2002. Estatística Aplicada à Experimentação Animal. 2a ed. Fundação de Estudo e Pesquisa em Medicina Veterinária e Zootecnia (FEPMVZ), Belo Horizonte. 265p.

Shalini A.S., Vijayakumar G., Kalaiselvi G., Raja A. \& Balasubramanium G.A. 2018. Molecular screening of Dirofilaria immitis in dogs from Namakkal District. Indian Vet. J. 95(1):55-57.

Silva A.M.A., Almeida K.S., Sousa J.J.N. \& Freitas F.L.C. 2008. Dirofilariose canina no município de Coari, Amazonas. Brasil. Arch. Vet. Sci. 13(2):145150. <http://dx.doi.org/10.5380/avs.v13i2.11613>

Simsek S., Ozkanlar Y., Balkaya I. \& Aktas M.S. 2011. Microscopic, serologic and molecular on Dirofilaria immitis in stray dogs, Turkey. Vet. Parasitol. 183(1/2):109-113. <http://dx.doi.org/10.1016/j.vetpar.2011.06.012> $<$ PMid:21757293>

Soares H.S., Camargo L.M.A., Gennari S.M. \& Labruna M.B. 2014. Survey of canine tick-borne diseases in Lábrea, Brazilian Amazon: 'accidental findings of Dirofilaria immitis infection'. Revta Bras. Parasitol. Vet. 23(4):473-480. <http://dx.doi.org/10.1590/s1984-29612014093><PMid:25517525>

Traversa D., Aste G., Milillo P., Capelli G., Pampurini F., Tunesi C., Santori D., Paoletti B. \& Boari A 2010. Autochthonous foci of canine and feline infections by Dirofilaria immitis. and Dirofilaria repens in central Italy. Vet. Parasitol. 169(1/2):128-132. <http://dx.doi.org/10.1016/j.vetpar.2009.12.034> $<$ PMid:20097479> 